\title{
Genetic mapping of resistance to Diuraphis noxia (Kurdjumov) biotype 2 in wheat (Triticum aestivum L.) accession CI2401
}

\author{
Mehdi Fazel-Najafabadi · Junhua Peng • \\ Frank B. Peairs · Hana Simkova • \\ Andrzej Kilian · Nora L. V. Lapitan
}

Received: 20 February 2014 / Accepted: 17 October 2014/Published online: 5 November 2014

(C) The Author(s) 2014. This article is published with open access at Springerlink.com

\begin{abstract}
The RWA, Diuraphis noxia (Kurdjumov), is a devastating insect pest of wheat (Triticum aestivum L.) and barley (Hordeum vulgare) in the United States and in many parts of the world. The use of D. noxia-resistant cultivars is an economically useful approach for protecting cereals from this aphid. However, there are few genes conferring resistance to the most predominant US biotype (Biotype RWA2). Wheat line CI2401, originating from Tajikistan, has been identified to be resistant to RWA2. An $\mathrm{F}_{2}$-derived $\mathrm{F}_{3}\left(\mathrm{~F}_{2: 3}\right)$ segregating population developed from a cross between CI2401 and Glupro (a high quality susceptible wheat cultivar) was used to genetically
\end{abstract}

Electronic supplementary material The online version of this article (doi:10.1007/s10681-014-1284-0) contains supplementary material, which is available to authorized users.

M. Fazel-Najafabadi · J. Peng · N. L. V. Lapitan Soil and Crop Science Department, Colorado State University, Fort Collins, CO 22046, USA

M. Fazel-Najafabadi

Agronomy and Plant Breeding Department, University College of Aburayhan, The University of Tehran, Tehran, Iran

J. Peng

Vegetable R \& D, Monsanto-China, Wuhan, Hubei, China

F. B. Peairs

Department of Bioagricultural Sciences and Pest Management, Colorado State University, Fort Collins, CO 22046, USA map the resistance in CI2401. Seedlings from $F_{2}$ individuals and $\mathrm{F}_{3}$ families were infested with RWA2 aphids. Seedling reactions were scored as resistant or susceptible based on the degrees of leaf rolling and chlorosis. The observed segregation ratios in the $F_{2}$ and $\mathrm{F}_{3}$ generations indicate the presence of a major dominant gene controlling resistance to RWA2. The gene, named Dn2401, was genetically mapped to the short arm of chromosome 7D. Xbarc214 mapped $1.1 \mathrm{cM}$ and $X g w m 473$ mapped $1.8 \mathrm{cM}$ distal and proximal, respectively, to the gene. Association studies using more than 12,000 SNPs and SilicoDArTs confirmed the presence of a major signal associated with resistance on chromosome 7DS. In addition, a minor signal was detected in chromosome 1D. The markers developed in this study will be useful for marker-assisted-breeding for resistance to RWA2.

H. Simkova Institute of Experimental Botany ASCR, Šlechtitelů 31, CZ-783 71, Olomouc, Czech Republic

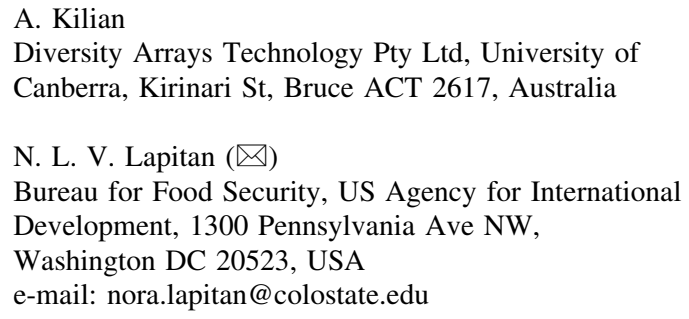


Keywords RWA resistance - RWA biotype 2 . Marker-assisted selection - Simple sequence repeat markers · Hordeum vulgare

$\begin{array}{ll}\text { Abbreviations } & \\ \text { RWA } & \text { Russian wheat aphid } \\ \text { RWA1, RWA2 } & \text { RWA biotype 1, biotype 2 } \\ \text { SSR } & \text { Simple sequence repeat } \\ \text { BSA } & \text { Bulked segregant analysis }\end{array}$

\section{Introduction}

The Russian wheat aphid (RWA), Diuraphis noxia (Kurdjumov) (Homoptera: Aphididae), is a major pest of wheat (T. aestivum L.) and barley (Hordeum vulgare L.). RWA was introduced into the U.S.A. in 1986 and by 1993 had caused direct and indirect losses to U.S. growers estimated at U.S. $\$ 893$ million (Morrison and Peairs 1998).

Plant damage from RWA infestations includes reduction of plant height, shoot weight, number of spikes, and yield (Girma et al. 1993). Susceptible symptoms include chlorosis, streaking along the entire leaf blade, leaf rolling, head trapping, and in severe cases, plant death (Burton and Webster 1993). These symptoms typically appear within seven days after the initial infestation. Once leaf rolling develops, it can hinder the effectiveness of contact insecticides by sheltering the insect colonies. The use of resistant varieties has been the most effective means of controlling this pest.

At least thirteen genes in wheat conferring resistance to RWA have been characterized and genetically mapped to either chromosome $1 \mathrm{D}$ or $7 \mathrm{D}$. These genes have been designated as Dn1 to Dn9, Dnx, Dny, Dn2414 and Dn626580 (Du Toit 1987, 1988, 1989; Du Toit et al. 1995; Liu et al. 2001, 2002, 2005; Ma et al. 1998; Marais and Du Toit 1993; Marais et al. 1994; Miller et al. 2001; Nkongolo et al. 1991; Peng et al. 2007; Saidi and Quick 1996; Schroeder-Teeter et al. 1993; Valdez et al. 2012). Resistant cultivars released in the U.S.A. have mainly relied on the single, dominant resistance gene Dn4 (Collins et al. 2005b; Quick et al. 1996). In Colorado, more than $25 \%$ of the wheat area has been planted to cultivars containing Dn4. In 2003, however, a new biotype discovered in Colorado destroyed all resistant cultivars. This new biotype, designated as RWA2, is virulent to all known resistance genes, except the rye gene $D n 7$ (Haley et al. 2004). RWA2 has since spread to other regions and is now the predominant biotype in the U.S. (Puterka et al. 2007). In the following two years, six additional biotypes were discovered in other states within the US Central Great Plains region (Weiland et al. 2008). The rapid outbreak of these biotypes within a short period emphasizes the need to identify resistance genes for new biotypes. A wheat gene for resistance to RWA2 recently identified from an Iranian landrace was designated as Dn626580 (Valdez et al. 2012).

Wheat cereal introduction 2401 (CI2401) from Tajikistan was resistant to the original biotype (RWA1) (Porter et al. 1993, 2005). After the appearance of RWA2, Collins et al. (2005a) screened 761 germplasm accessions previously determined to be resistant to RWA) and showed that CI2401 also has resistance to RWA2. CI2401 was further shown to be resistant to all eight known biotypes existing in the U.S. (Weiland et al. 2008). Qureshi et al. (2006) confirmed resistance of CI2401 to RWA2. With regard to the number of resistance genes in CI2401, Dong et al. (1997) reported that there are two genes in CI2401 for resistance to biotype RWA1, one of which is Dn4 located on chromosome 1D. Voothuluru et al. (2006) also reported the likely presence of two dominant genes conferring resistance to RWA2 in CI2401. As pointed out by Voothuluru et al. (2006), one of the genes could not be Dn4 since RWA2 is virulent to Dn4. The resistance gene(s) in CI2401 have not been genetically mapped.

Molecular markers linked to resistance genes are useful for marker-assisted selection (MAS). Simple sequence repeats (SSRs) are useful for MAS in wheat because of their ease of use and relatively low cost (Peng et al. 2009; Plaschke et al. 1995; Röder et al. 1995). Although high throughput genotyping is now available for wheat (Akhunov et al. 2009; Berard et al. 2009; Poland et al. 2012), SSRs continue to be used, particularly for mapping single genes in defined chromosome locations (Huang et al. 2014; Niu et al. 2014).

This study was conducted to map the resistance gene(s) in CI2401 and develop SSR markers for marker-assisted breeding. 


\section{Materials and methods}

Plant materials

An $F_{2}$ population consisting of 158 plants was developed from a cross between CI2401 (PI9781), a RWA resistant winter wheat accession originating from Tajikistan (Collins et al. 2005a; Dong et al. 1997; Randolph et al. 2009) and 'Glupro' (PI 592759), a RWA susceptible, hard red spring wheat containing a high grain protein content gene in chromosome 6B transferred from $T$. turgidum ssp. dicoccoides (Mesfin et al. 1999). One hundred and thirty-six $F_{2: 3}$ families were used for mapping.

To verify the mapping results, high resolution mapping was conducted using a total of 64 lines derived from reciprocal crosses CI2401 $\times$ Glupro (35 lines) and Glupro $\times$ CI2401 (29 lines). Fifty-one were $\mathrm{F}_{2: 3}$ families, seven $\mathrm{F}_{3}$, three $\mathrm{F}_{4}$ and three $\mathrm{F}_{5}$ families. Ten of these lines were analyzed in duplicate, using both the DNA coming from plants used for RWA screening and their sister plants grown in different conditions, respectively. Four to twelve plants per family were screened for RWA response.

RWA screening and phenotyping

Standard seedling screening procedures were employed for evaluation of RWA2 resistance (Nkongolo et al. 1991). RWA screening was conducted at the CSU Insectary under ambient conditions $(14 \mathrm{~h}$ and $\sim 25.5^{\circ} \mathrm{C}$ with light intensities between 1,100 and $1,400 \mu \mathrm{M} \mathrm{m}^{2} \mathrm{~s}^{-1}$ and $10 \mathrm{~h}$ and $\sim 20^{\circ} \mathrm{C}$ nights). $\mathrm{F}_{2}$ seeds were also planted in $20 \times 30 \mathrm{~cm}$ pots, with two plants per pot. To save the seedlings after assessment of RWA response, aphids were removed using Imidacloprid $^{\circledR}$, a systemic insecticide for soil drenching. For screening $\mathrm{F}_{2: 3}$ families, a randomized complete block design with three replications was performed. Eight seeds per $\mathrm{F}_{2: 3}$ family were planted in a row in a $52.0 \times 25.5 \mathrm{~cm}$ tray, with 34 families and the resistant (CI2401) and susceptible (Glupro) parents included in each tray. There were four trays per block.

Seedlings at the one-leaf stage were infested with RWA2 as described in Nkongolo et al. (1991). Symptom development was assessed at 7 and $14 \mathrm{~d}$ after infestation, and was scored for leaf rolling and chlorosis. Chlorosis scores were from one for healthy seedlings with small hypersensitive lesions to nine for dead or unrecoverable seedlings whereas leaf rolling scores were on a scale of one for completely flat leaves to four for tightly rolled leaves with leaf trapping (Webster et al. 1987). Seedlings with chlorosis scores of $\leq 4$ and leaf rolling scores $\leq 2$ were considered resistant and those exhibiting chlorosis $\geq 5$ and leaf rolling $\geq 3$ were considered susceptible. Progeny tested $\mathrm{F}_{2}$ individuals were assigned a phenotypic class (homozygous resistant $[\mathrm{R}]$, heterozygous $[\mathrm{H}]$, or homozygous susceptible [S]) based on the numbers of observed resistant and susceptible individuals. Homozygous resistant and susceptible designations were only assigned to $F_{2}$ individuals when all (or all but one) of the seedlings in the $\mathrm{F}_{2: 3}$ family were given the corresponding designation (Valdez et al. 2012).

DNA isolation, PCR, and genetic mapping

An appropriate amount ( $\sim 1.0 \mathrm{~g})$ of young leaf tissue was collected from each $F_{2}$ plant and stored in a $-20{ }^{\circ} \mathrm{C}$ freezer until use. DNA isolation was performed according to Edwards et al. (1991) and its quality and quantity verified using $1 \%$ agarose gels and DNA standards with known concentrations. Equal amounts of DNA extracted from 10 resistant and 10 susceptible plants were bulked separately for bulked segregant analysis (Michelmore et al. 1991).

More than 300 SSR markers were initially screened for polymorphism between the resistant and susceptible parents, and between resistant and susceptible bulks consisting of 10 resistant and 10 susceptible F2 progeny. Forty-two markers showing polymorphisms between the parents and representing each chromosome arm of wheat were mapped in $136 \mathrm{~F}_{2: 3}$ families (Supplementary Table). An additional 35 SSR markers from the short arm of chromosome 7D were screened for polymorphism between the parents and resistant and susceptible bulks. Of these, 7 showed polymorphisms and were used to further refine the map (Supplementary Table).

Seventy to $100 \mathrm{ng}$ of genomic DNA was used in each PCR. PCR was conducted according to Peng et al. (2009). PCR products were separated on $3 \%$ agarose gels at 90 watts power for $6 \mathrm{~h}$ in $1 \times$ TAE buffer, or on $5 \%$ denaturing polyacrylamide gels (19:1 acrylamide:Bis, $8 \mathrm{M}$ urea) at 70 watts for $2.5 \mathrm{~h}$ in $1 \times$ TBE buffer. PCR products were detected by $0.5 \mu \mathrm{g} \mathrm{ml}^{-1} \mathrm{EtBr}$ for agarose gels and silver staining 
according to the manufacturer's instructions (Promega, Madison, WI) for polyacrylamide gels.

Genetic mapping was conducted using MapMaker 3.0 (Lander et al. 1987) and JoinMap 4.0 (Van Ooijen 2006). Centimorgan units were calculated using the Haldane (1919) mapping function.

\section{High resolution mapping by DArtseq}

High resolution mapping was performed at Diversity Arrays Technology Pty Ltd (Canberra, Australia) as previously described (Courtois et al. 2013; Cruz et al. 2013; Raman et al. 2014). A complexity reduction method optimized for wheat (PstI-HpaII) was used to generate genomic representations (libraries), which were sequenced on an IlluminaHiseq 2000 next generation sequencer. Each sample was processed separately and 35 were done twice. This level of technical replication combined with the replication at the level of plant material (10 replicates mentioned above) translates to over $50 \%$ overall replication. Approximately 2,000,000 reads were generated for each DNA samples and after poor quality read filtering and demultiplexing (using barcoded adaptor sequences) the sequences were processed using a DArTsoft14 program implemented in a KDCompute plug-in system (http://www.diversityarrays.com/kddart). Both SNPs and SilicoDArT markers (presence/absence of restriction fragment in genomic representation) were extracted with the accompanying metadata (including average marker reproducibility calculated from technical replicates).

\section{Statistical analyses}

Chi squared tests for goodness of fit to phenotypic segregation ratios of 3:1 (resistant: susceptible) and genotypic segregation ratios of 1:2:1 (homozygous resistant: heterozygous: homozygous susceptible) were made to test genetic hypotheses on the mode of inheritance of RWA resistance and DNA markers.

For high resolution mapping a set of high quality SNPs $(5,901)$ and SilicoDArTs $(6,203)$ were used in statistical analysis of association between markers and chlorosis (based on 1-9 scores) and leaf rolling (based on 1-4 scores). linear model, linear mixed model and statistical machine learning (Bedo et al. 2008) were used in the analyses.
Table 1 SSR markers on chromosome 7DS showing polymorphism between resistant and susceptible parents and bulks

\begin{tabular}{lll}
\hline Marker & \multicolumn{2}{l}{ Polymorphic band sizes (bp) } \\
\cline { 2 - 3 } & CI2401 & Glupro \\
\hline Xbarc126 & 335 & 315 \\
Xbarc128 & 390 & 385 \\
Xbarc172 & 368 & 375 \\
Xbarc214 & 317 and 310 & 321 and 312 \\
Xcfd14 & 275 and 282 & 272 and 280 \\
Xcfd68 & 237 and 210 & 233 and 206 \\
Xgwm111 & 274 & 288 \\
Xgwm121 & 240 & 220 \\
Xgwm473 & 370 and 380 & 395 and 400 \\
\hline
\end{tabular}

\section{Results}

Inheritance of resistance in CI2401

Following infestation with RWA2, the $\mathrm{F}_{2}$ progeny from CI2401/Glupro segregated $116(73.4 \%)$ resistant: $42(26.6 \%)$ susceptible, fitting a $3: 1$ phenotypic segregation $\left(\chi^{2}=0.21, P=0.646\right)$. The $\mathrm{F}_{2: 3}$ families were distributed 26 homozygote resistant, 77 heterozygous, and 33 homozygote susceptible, fitting a 1:2:1 genotypic segregation ratio $\left(\chi^{2}=3.10, P=0.212\right)$. The segregation of both $F_{2}$ and $F_{3}$ progeny agree with the presence of a single dominant gene conferring resistance. The gene was temporarily designated Dn2401.

Genetic mapping of Dn2401

In order to map the resistance gene in CI2401, a survey of SSR markers from each of the chromosome arms of wheat was first conducted. More than 300 markers selected from previous wheat maps (Guyomarc'h et al. 2002; Peng and Lapitan 2005; Roder et al. 1998; Somers et al. 2004; Song et al. 2002) were initially screened for polymorphism between the resistant and susceptible parents, and between resistant and susceptible bulks. A total of 42 polymorphic markers, two from each chromosome, were identified (Table 1S). Of these, only two markers, Xbarc126 and Xgwm121, showed polymorphism between the parents as well as between the resistant and susceptible bulks. Both markers were previously mapped to chromosome 7D (Roder et al. 1998; Song et al. 2002). We then screened 
Table 2 Segregation of markers linked to Dn2401 and their relative locations in chromosome 7DS

\begin{tabular}{|c|c|c|c|c|c|c|c|c|}
\hline Marker & $\begin{array}{l}\text { No. of families } \\
\text { with resistant } \\
\text { parent allele }\end{array}$ & $\begin{array}{l}\text { No. of } \\
\text { heterozygoous } \\
\text { families }\end{array}$ & $\begin{array}{l}\text { No. of families } \\
\text { with susceptible } \\
\text { parent allele }\end{array}$ & $\begin{array}{l}\text { Missing } \\
\text { data }\end{array}$ & $\chi^{2} \quad 1: 2: 1$ & $P$ value & $\begin{array}{l}\text { Distance from } \\
\text { previous } \\
\text { marker }\end{array}$ & Position \\
\hline Xgwm121 & 38 & 79 & 41 & 0 & 0.11 & 0.946 & 0.00 & 0.00 \\
\hline Xbarc172 & 30 & 84 & 43 & 1 & 2.92 & 0.232 & 20.9 & 20.9 \\
\hline Xcfd14 & 30 & 83 & 45 & 0 & 3.25 & 0.197 & 10.8 & 31.7 \\
\hline Xbarc128 & 30 & 82 & 44 & 2 & 2.92 & 0.232 & 0.6 & 32.3 \\
\hline Xgwm473 & 29 & 77 & 42 & 10 & 2.53 & 0.282 & 0.4 & 32.7 \\
\hline Dn2401 & 26 & 77 & 33 & 22 & 3.10 & 0.212 & 1.8 & 34.5 \\
\hline Xbarc 214 & 31 & 81 & 44 & 2 & 2.40 & 0.131 & 1.1 & 35.6 \\
\hline Xcfd68 & 31 & 83 & 43 & 1 & 2.35 & 0.309 & 0.3 & 35.9 \\
\hline Xgwm111 & 30 & 82 & 44 & 2 & 2.92 & 0.232 & 2.6 & 38.5 \\
\hline Xbarc126 & 41 & 76 & 41 & 0 & 0.23 & 0.891 & 35.4 & 73.9 \\
\hline
\end{tabular}

7DS

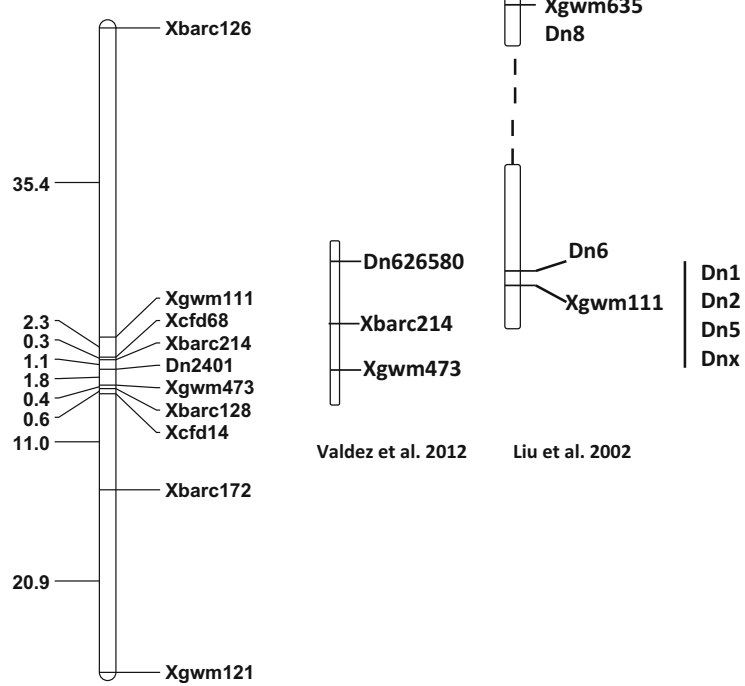

Fig. 1 Linkage map of wheat chromosome 7DS containing Dn2401 (this study) and comparative maps from the literature

an additional 35 markers from the short and long arms of chromosome 7D. Nine markers, all previously mapped to the short arm of chromosome 7D (Roder et al. 1998; Somers et al. 2004) were polymorphic between the resistant and susceptible parents (Table 1). Markers Xbarc214, Xcfd14, Xcfd68, and Xgwm 473 generated two bands in each parent. In these cases, the segregations of all bands were scored. All nine markers were co-dominant (Table 1$) \cdot \chi^{2}$ tests for goodness of fit did not detect any deviation from a 1:2:1 ratio (Table 2).

Genetic mapping of the nine markers resulted in a map with a total genetic distance of $73.9 \mathrm{cM}$ (Fig. 1). Xbarc126 and Xgwm121 were furthest from Dn2401 on opposite ends of the map. Xbarc126 was $35.4 \mathrm{cM}$ from the closest marker, Xgwm111, while Xgwm121 was $20.9 \mathrm{cM}$ from $X$ barc172. Six markers were closely linked with Dn2401, covering a total genetic distance of $6.5 \mathrm{cM}$. The closest markers flanking Dn2401 were Xgwm473 and Xbarc214, which were 1.8 and $1.1 \mathrm{cM}$ from the gene, respectively.

In order to verify these results, high-resolution mapping using a DArTseq platform was conducted on recombinant progenies derived from the original mapping population. More than 12,000 markers $(5,901$ SNPs and 6,203 SilicoDArTs) were used in association analyses with the quantitative scores for chlorosis and leaf rolling. All three models used for the statistical analyses (linear model, linear mixed model and statistical machine learning) detected a strong signal on chromosome 7D with at least 10 markers around position $170 \mathrm{cM}$ in the wheat consensus map developed by DArT PL (http://www.diversityarrays. com/sequence-maps). Due to presence of a large number of markers (over 3,400 markers), the total length of the consensus map for chromosome 7D is $370 \mathrm{cM}$. The position of a cluster of markers associated with both chlorosis and leaf rolling mapped to the short arm. However, there was a much weaker signal at approximately $40 \mathrm{cM}$ on chromosome $1 \mathrm{D}$, which is 
represented by nearly 2,000 markers and covers almost $270 \mathrm{cM}$.

\section{Discussion}

The mode of inheritance of resistance to biotype RWA2 in wheat line CI2401 was consistent with that expected for a single dominant gene. Survey screening of markers from the entire wheat genome for polymorphisms between resistant and susceptible bulks showed an association of resistance with chromosome 7D. Genetic mapping of markers from chromosome 7D resulted in a map with nine markers covering a genetic distance of $73.9 \mathrm{cM}$. Six of these markers were closely linked to Dn2401 in a region covering 6.5 cM. The nine markers were previously mapped to chromosome 7DS (Roder et al. 1998; Somers et al. 2004), and were oriented in the same order as the map of Somers et al. (2004). Using markers derived from 7DS flow-sorted chromosomes, Simkova et al. (2011) demonstrated an ability to build a high resolution map around markers shown to be linked to RWA resistance in CI2401 in this study. Association analyses using more than 12,000 SNPs and the quantitative scores for leaf rolling and chlorosis have now confirmed a major locus for both traits in chromosome 7DS. Collectively, these results support the conclusion that a major locus designated Dn2401 for resistance to RWA2 in CI2401 is located in chromosome 7DS.

High resolution mapping conducted on recombinant progenies also detected a weak signal associated with leaf rolling and chlorosis in chromosome 1D. This suggests the presence of a second gene with minor effect contributing to resistance in CI2401. This result is supported by the previous study of Voothuluru et al. (2006) suggesting the likely presence of two genes conferring resistance in CI2401 based on segregation of $F_{2}$ and $F_{4}$ progenies from a cross between CI2401 and the susceptible parent 'Karl'. This minor gene effect was possibly not detected in our inheritance studies using $\mathrm{F}_{2}$ and $\mathrm{F}_{3}$ populations because chlorosis and leaf rolling scores were combined to categorize the responses as resistant or susceptible. In the high resolution studies on the recombinant progeny, the leaf rolling and chlorosis scores were kept separate, thus allowing detection of a minor effect.
Seven genes for resistance to RWA were previously mapped on chromosome 7DS. These include Dn1, Dn2, Dn5, Dn6, Dn8, and Dnx, which all confer resistance to RWA1 (Du Toit et al. 1995; Liu et al. 2001, 2002, 2005; Ma et al. 1998; Marais and Du Toit 1993; Miller et al. 2001; Schroeder-Teeter et al. 1993). The recently mapped Dn626580, which confers resistance to RWA2, is also on this chromosome arm (Valdez et al. 2012). Xgwm111, which is $4.0 \mathrm{cM}$ from Dn2401, is also linked to Dn1, Dn2, Dn5, Dn6, and Dnx (Liu et al. 2001, 2002, 2005; Miller et al. 2001). Whether these genes are allelic or represent a cluster of genes linked to Xgwm111 is yet to be determined. SSR markers Xbarc214 and Xgwm473 are also linked to Dn626580 (Valdez et al. 2012). The difference is that whereas Xbarc214 and Xgwm473 flank Dn2401 in our study, they were proximal to Dn626580 in the Valdez et al. report. This suggests that Dn2401 might not be allelic to Dn626580. It is interesting to note that while chromosome 7DS contains multiple genes for resistance to RWA, 7DL has multiple genes for resistance to greenbug, Schizapis graminum Rondani (Zhu et al. 2005).

Several genes for resistance to RWA have been mapped to wheat chromosome 1D (Liu et al. 2002; Ma et al. 1998). CI2401 was previously reported to contain Dn4, which maps to chromosome 1D (Ma et al. 1998). However, Dn4 does not confer resistance to RWA2 (Dong et al. 1997). It therefore appears that a gene other than $\mathrm{Dn} 4$ is responsible for the minor effect detected in chromosome 1D.

RWA2 is currently the most widely virulent of the eight known biotypes of RWA in the U.S.A. (Puterka et al. 2007). To date, resistance to RWA2 has been identified in only a few wheat lines including STARS2414 and PI 626580 (Puterka et al. 2013; Randolph et al. 2009; Valdez et al. 2012). Synthetic hexaploids from CIMMYT with resistance to RWA2 have also been reported (Sotelo et al. 2009). However, only two other genes with resistance to RWA2, Dn7 and Dn626580, were genetically characterized and mapped prior to this study (Anderson et al. 2003; Lapitan et al. 2007; Valdez et al. 2012). The markers developed in our study will be useful for MAS of Dn2401 in wheat breeding programs.

Acknowledgments This study was supported in part by the Colorado Wheat Research Foundation, the U.S. Department of Agriculture under Cooperative Agreements USDA Contract No. 
2009-34205-19960 and 2010-34205-21350, and Hatch Funds Project No. 644. M.F. was supported through a fellowship from the University of Tehran. The DArTseq studies were supported by the Czech Science Foundation Award No. P501/12/2554. We thank Jeff Rudolph (Department of Bioagricultural Sciences and Pest Management, Colorado State University, Fort Collins, CO, USA) for providing the RWA used in these experiments.

Open Access This article is distributed under the terms of the Creative Commons Attribution License which permits any use, distribution, and reproduction in any medium, provided the original author(s) and the source are credited.

\section{References}

Akhunov E, Nicolet C, Dvorak J (2009) Single nucleotide polymorphism genotyping in polyploid wheat with the Illumina goldengate assay. Theor Appl Genet 119:507-517

Anderson G, Papa D, Peng J, Tahir M, Lapitan NV (2003) Genetic mapping of Dn7, a rye gene conferring resistance to the Russian wheat aphid in wheat. Theor Appl Genet 107:1297-1303

Bedo J, Wenzl P, Kowalcyzk A, Kilian A (2008) Precisionmapping and statistical validation of quantitative trait loci by machine learning. BMC Genet 9:35-52

Berard A, Le Paslier MC, Dardevet M, Exbrayat-Vinson F, Bonnin I, Cenci A, Haudry A, Brunel D, Ravel C (2009) High-throughput single nucleotide polymorphism genotyping in wheat (Triticum spp.). Plant Biotech J 7:364-374

Burton RL, Webster JA (1993) Evaluation of Russian wheat aphid (Homoptera: Aphididae) damage on resistant and susceptible hosts with comparisons of damage ratings to quantitative plant measurements. J Econ Entom 86:974-980

Collins MB, Haley SD, Peairs FB, Rudolph JB (2005a) Biotype 2 Russian wheat aphid resistance among wheat germplasm accessions. Crop Sci 45:1877-1880

Collins MB, Haley SD, Randolph TL, Peairs FB, Rudolph JB (2005b) Comparison of Dn4- and Dn7-carrying spring wheat genotypes artificially infested with Russian wheat aphid (Homoptera: Aphididae) biotype 1. J Econ Entomol 98:1698-1703

Courtois B, Audebert A, Dardou A, Roques S, Ghneim- Herrera $\mathrm{T}$ (2013) Genome-wide association mapping of root traits in a japonica rice panel. PLoS ONE 8(11):e78037

Cruz VM, Kilian A, Dierig DA (2013) Development of DArT marker platforms and genetic diversity assessment of the U.S. collection of the new oilseed crop lesquerella and related species. PLoS ONE 8(5):e64062

Dong H, Quick JS, Zhang Y (1997) Inheritance and allelism of Russian wheat aphid resistance in several wheat lines. Plant Breed 116:449-453

Du Toit F (1987) Resistance in wheat (Triticum aestivum) to Diuraphis noxia (Homoptera: Aphididae). Cereal Res Commun 15:175-179

Du Toit F (1988) A greenhouse test for screening wheat seedlings for resistance to the Russian wheat aphid, Diuraphis noxia (Homoptera: Aphididae). Phytophylactica 20: 321-322
Du Toit F (1989) Inheritance of resistance in two Triticum aestivum lines to Russian wheat aphid (Hornoptera: Aphididae). J Econ Entom 82:1251-1253

Du Toit F, Wessel WG, Marais GF (1995) The chromosome arm location of the Russian wheat aphid resistance gene, Dn5. Cereal Res Commun 23:15-17

Edwards K, Johnstone C, Thompson C (1991) A simple and rapid method for the preparation of plant genomic DNA for PCR analysis. Nuc Acids Res 19:1349

Girma M, Wilde GE, Harvey TL (1993) Russian wheat aphid (Homoptera: Aphididae) affects yield and quality of wheat. J Econ Entom 86:594-601

Guyomarc'h H, Sourdille P, Charmet G, Bernard M (2002) Characterisation of polymorphic microsatellite markers from Aegilops tauschii and transferability to the D-genome of bread wheat. Theor Appl Genet 104:1164-1172

Haldane J (1919) The probable errors of calculated linkage values, and the most accurate method of determining gametic from certain zygotic series. J Genet 8:291-297

Haley SD, Peairs FB, Walker CB, Rudolph JB, Randolph TL (2004) Occurrence of a new Russian wheat aphid biotype in Colorado. Crop Sci 44:1589-1592

Huang Q, Li X, Chen WQ, Xiang ZP, Zhong SF, Chang ZJ, Zhang M, Zhang HY, Tan FQ, Ren ZL, Luo PG (2014) Genetic mapping of a putative Thinopyrum intermediumderived stripe rust resistance gene on wheat chromosome 1B. Theor Appl Genet 127:843-853

Lander ES, Green P, Abrahamson J, Barlow A, Daly MJ, Lincoln SE, Newburg L (1987) MAPMAKER: An interactive computer package for constructing primary genetic linkage maps of experimental and natural populations. Genomics 1:174-181

Lapitan NLV, Peng J, Sharma V (2007) A high-density map and PCR markers for Russian wheat aphid resistance gene Dn7 on chromosome 1RS/1BL. Crop Sci 47:811-818

Liu XM, Smith CM, Gill BS, Tolmay V (2001) Microsatellite markers linked to six Russian wheat aphid resistance genes in wheat. Theor Appl Genet 102:504-510

Liu XM, Smith CM, Gill BS (2002) Identification of microsatellite markers linked to Russian wheat aphid resistance genes Dn4 and Dn6. Theor Appl Genet 104:1042-1048

Liu XM, Smith CM, Friebe BR, Gill BS (2005) Molecular mapping and allelic relationships of Russian wheat aphid resistance genes. Crop Sci 45:2273-2280

Ma ZQ, Saidi A, Quick JS, Lapitan NLV (1998) Genetic mapping of Russian wheat aphid resistance genes Dn2 and Dn4 in wheat. Genome 41:303-306

Marais GF, Du Toit F (1993) A monosomic analysis of Russian wheat aphid resistance in the common wheat PI 294994. Plant Breed 111:246-248

Marais GF, Horn M, Du Toit F (1994) Intergeneric transfer (rye to wheat) of a gene(s) for Russian wheat aphid resistance. Plant Breed 113:265-271

Mesfin A, Frohberg RC, Anderson JA (1999) RFLP markers associated with high grain protein from Triticum turgidum L. var. dicoccoides introgressed into hard red spring wheat. Crop Sci 39:508-513

Michelmore RW, Paran I, Kesseli RV (1991) Identification of markers linked to disease-resistance genes by bulked segregant analysis: a rapid method to detect markers in specific 
genomic regions by using segregating populations. Proc Natl Acad Sci USA 88:9828-9832

Miller CA, Altinkut A, Lapitan NLV (2001) A microsatellite marker for tagging a wheat gene conferring resistance to the Russian wheat aphid. Crop Sci 41:1584-1589

Morrison WP, Peairs FB (1998) Introduction, response model concept and economic impact. In: Quisenberry SS, Peairs FB (eds) A response model for an introduced pest-the Russian wheat aphid. Thomas Say Publisher in Entomology, Entomol Soc America, Lanham, Maryland, pp 1-11

Niu Z, Klindworth DL, Yu G, LF T, Chao S, Jin Y, Cai X, Ohm JB, Rasmussen JB, Xu SS (2014) Development and characterization of wheat lines carrying stem rust resistance gene $\mathrm{Sr} 43$ derived from Thinopyrum ponticum. Theor Appl Genet 127:969-980

Nkongolo KK, Quick JS, Peairs FB, Meyer WL (1991) Inheritance of resistance of PI 372129 wheat to the Russian wheat aphid. Crop Sci 31:905-907

Peng JH, Lapitan NL (2005) Characterization of EST-derived microsatellites in the wheat genome and development of eSSR markers. Func Integr Genomics 5:80-96

Peng J, Wang H, Haley SD, Peairs FB, Lapitan NLV (2007) Molecular mapping of the Russian wheat aphid resistance gene Dn2414 in wheat. Crop Sci 47:2418-2429

Peng J, Bai Y, Haley S, Lapitan N (2009) Microsatellite-based molecular diversity of bread wheat germplasm and association mapping of wheat resistance to the Russian wheat aphid. Genetica 135:95-122

Plaschke J, Ganal MW, Röder MS (1995) Detection of genetic diversity in closely related bread wheat using microsatellite markers. Theor Appl Genet 91:1001-1007

Poland JA, Brown PJ, Sorrells ME, Jannink JL (2012) Development of high-density genetic maps for barley and wheat using a novel two-enzyme genotyping-by-sequencing approach. PloSOne 7:e32253

Porter DR, Webster JA, Baker CA (1993) Detection of resistance to the Russian wheat aphid in hexaploid wheat. Plant Breed 110:157-160

Porter DR, Baker CA, El-Bouhssini M (2005) Resistance in wheat to a new North American-Russian wheat aphid biotype. Plant Breed 124:603-604

Puterka GJ, Burd JD, Porter D, Shufran K, Baker C, Bowling B, Patrick C (2007) Distribution and diversity of Russian wheat aphid (Hemiptera: Aphididae) biotypes in North America. J Econ Entom 100:1679-1684

Puterka GJ, Nicholson SJ, Brown MJ, Hammon RW (2013) Response of Russian wheat aphid aesistance in wheat and barley to four Diuraphis (Hemiptera: Aphididae) species. J Econ Entom 106:1029-1035

Quick JS, Ellis GE, Normann RM, Stromberger JA, Shanahan JF, Peairs FB, Rudolph JB, Lorenz K (1996) Registration of 'Halt' wheat. Crop Sci 36:210

Qureshi JA, Michaud JP, Martin TJ (2006) Resistance to biotype 2 Russian wheat aphid (Homoptera: Aphididae) in two wheat lines. J Econ Entom 99:544-550

Raman H, Raman R, Kilian A, Detering F, Carling J et al (2014) Genome-wide delineation of natural variation for pod shatter resistance in Brassica napus. PLoS ONE 9(7): e101673
Randolph TL, Peairs F, Weiland A, Rudolph JB, Puterka GJ (2009) Plant responses to seven Russian wheat aphid (Hemiptera: Aphididae) biotypes found in the United States. J Econ Entom 102:1954-1959

Roder MS, Korzun V, Wendehake K, Plaschke J, Tixier MH, Leroy P, Ganal MW (1998) Microsatellite map wheat. Genet 149:2007-2023

Röder MS, Plaschke J, König SU, Börner A, Sorrells ME, Tanksley SD, Ganal MW (1995) Abundance, variability and chromosomal location of microsatellites in wheat. Mol General Genet 246:327-333

Saidi A, Quick JS (1996) Inheritance and allelic relationships among Russian wheat aphid resistance genes in winter wheat. Crop Sci 36:256-258

Schroeder-Teeter S, Zemetra RS, Schotzko DJ, Smith CM, Rafi M (1993) Monosomic analysis of Russian wheat aphid (Diuraphis noxia) resistance in Triticum aestivum line PI137739. Euphytica 74:117-120

Simkova H, Safar J, Kubalakova M, Suchankova P, Cihalikova J, Robert-Quatre H, Azhaguvel P, Weng Y, Peng J, Lapitan NL, Ma Y, You FM, Luo MC, Bartos J, Dolezel J (2011) BAC libraries from wheat chromosome 7D: efficient tool for positional cloning of aphid resistance genes. J Biomed Biotechnolog 2011:302543. doi:10.1155/2011/302543

Somers D, Isaac P, Edwards K (2004) A high-density microsatellite consensus map for bread wheat (Triticum aestivum L.). Theor Appl Genet 109:1105-1114

Song QJ, Fickus EW, Cregan PB (2002) Characterization of trinucleotide motifs in wheat. Theor Appl Genet 104: 286-293

Sotelo P, Starkey S, Voothuluru P, Wilde GE, Smith CM (2009) Resistance to Russian wheat aphid biotype 2 in CIMMYT synthetic hexaploid wheat lines. J Econ Entom 102: 1255-1261

Valdez VA, Byrne PF, Lapitan NLV, Peairs FB, Bernardo A, Bai G, Haley SD (2012) Inheritance and genetic mapping of Russian wheat aphid resistance in Iranian wheat landrace accession PI 626580. Crop Sci 52:676-682. doi:10. 2135/cropsci2011.06.0331

Van Ooijen JW (2006) JoinMap ${ }^{\circledR} 4$, Software for the calculation of genetic linkage maps in experimental populations. In: Kyazma BV, Wageningen

Voothuluru P, Meng J, Khajuria C, Louis J, Zhu L, Starkey S, Wilde GE, Baker CA, Smith CM (2006) Categories and inheritance of resistance to Russian wheat aphid (Homoptera: Aphididae) biotype 2 in a selection from wheat cereal introduction 2401. J Econ Entom 99:1854-1861

Webster JA, Starks KJ, Burton RL (1987) Plant resistance studies with Diuraphis noxia (Homoptera: Aphididae), a new United States wheat pest. J Econ Entom 80:944-949

Weiland AA, Peairs FB, Randolph TL, Rudolph JB, Haley SD, Puterka GJ (2008) Biotypic diversity in Colorado Russian wheat aphid (Hemiptera: Aphididae) populations. J Econ Entom 101:569-574

Zhu LC, Smith CM, Fritz A, Boyko E, Voothuluru P, Gill BS (2005) Inheritance and molecular mapping of new greenbug resistance genes in wheat germplasms derived from aegilops tauschii. Theor Appl Genet 111:831-837 